\section{Assessment of tank sediments in terms of plant nutrients equivalent: an approach towards agricultural sustainability}

\author{
Bisweswar Gorain $^{1, *}$, V. R. Ramakrishna Parama ${ }^{2}$ \\ and Srijita Paul ${ }^{3}$ \\ ${ }^{1}$ Department of Soil Science, ICAR-Central Soil Salinity Research \\ Institute, RRS, Bharuch 392 012, India \\ ${ }^{2}$ Department of Soil Science, University of Agricultural Sciences, \\ Bengaluru 560 064, India \\ ${ }^{3}$ Agricultural Training Centre and State Agricultural Management and \\ Extension Training Institute, Ramakrishna Mission, Narendrapur, \\ Kolkata 700 103, India
}

The aim of this study was to assess the suitability of lake sediments of Bengaluru, Karnataka, India, as a nutrient source for agricultural crop production. The sediments were analysed for macro- and micronutrients and toxic heavy metals using standard procedures. The results showed high stocks of $N, P$ and $K$ and low heavy metal concentration in the upper $15 \mathrm{~cm}$ depth of the lake sediments, implying their suitability as a nutrient alternative. This will reduce the use of synthetic fertilizers, improve soil health and also increase water storage capacity in the lakes, and thus promote sustainable agricultural production.

Keywords: Food security, heavy metals, plant nutrients, surface-water run-off, sustainable agriculture, tank sediments.

THE judicious use and management of natural resources, viz. soil and water are vital for sustainable agriculture. In order to meet the growing demand for food, feed and fibre on a sustainable basis, proper soil management and rainwater conservation are essential. Due to the increasing demand for agricultural products, over-exploitation and inappropriate management of natural resources have become a common phenomenon. As a consequence, surface-water run-off, downstream flooding, soil erosion, loss of nutrient-rich topsoil and water scarcity are leading to soil degradation. The surface run-off erodes the topsoil, which finally gets deposited in the nearby water bodies ${ }^{1}$. Loss of nutrients and organic matter from farmlands reduces agricultural productivity and may threaten food security. Modern agricultural practices depend on synthetic fertilizers, pesticides and herbicides for crop production. Run-off from these farmlands not only erodes the topsoil and fine organic matter particulates, but also the heavy metals (component of pesticides and herbicides) $)^{2}$.

Many household drains and industries in Bengaluru, Karnataka, India have their outlets in lakes ${ }^{3}$. Thus, essen-

\footnotetext{
*For correspondence. (e-mail: Bisweswar.Gorain@icar.gov.in)
}

tial nutrients and heavy metals from all these sources are finally accumulated in the tank sediments. These sediments can thus be used as a nutrient source in agriculture provided their heavy metal concentrations are within the threshold levels ${ }^{4}$. This not only saves the cost of synthetic fertilizers but can also moderate soil physical, chemical and biological properties, thereby improving soil health ${ }^{5}$. The desiltation of sediments also has the potential to increase the water storage capacity in the lakes and help in rainwater harvesting. With this background, sediments from nine different lakes in Bengaluru were collected and analysed for available plant macro- and micronutrients and heavy metal concentration, to assess their suitability as an alternate source of plant nutrients.

The city of Bengaluru stretches from $12^{\circ} 59^{\prime \prime} \mathrm{N}$ to $77^{\circ} 57^{\prime \prime} \mathrm{E}$, located equidistant from the eastern and western coasts of the South Indian peninsula. It is situated at an altitude of $920 \mathrm{~m}$ amsl, with mean annual rainfall of about $880 \mathrm{~mm}$. The summer and winter temperatures range from $18^{\circ} \mathrm{C}$ to $38^{\circ} \mathrm{C}$ and $12^{\circ} \mathrm{C}$ to $25^{\circ} \mathrm{C}$ respectively. The city delineates four watersheds, viz. Hebbal, Koramangala, Challaghatta and Vrishabhavathi ${ }^{6}$. Recent satellite imagery data suggest that the number of lakes has dropped from 262 (in 1961) to about 30, mostly due to encroachments, silt deposition and mismanagement. Table 1 shows the coordinates and extent of nine lakes of Bengaluru considered in the present study. Samples of tank silt were collected up to $15 \mathrm{~cm}$ depth at various locations in the tank-bed area. A composite sample was drawn using normal sampling procedure. The soil samples and tank sediments were dried in shade, ground with a wooden pestle and mortar and finally passed through a $2 \mathrm{~mm}$ sieve and stored in clean polythene bags for further analyses. Analysis of $\mathrm{N}, \mathrm{P}, \mathrm{K}, \mathrm{Ca}, \mathrm{Mg}$ and $\mathrm{S}$ was done using standard procedures (Table 2). Micronutrients and heavy metals were analysed by diethylene triamine pentaacetic acid (DTPA) extraction method using atomic absorption spectrophotometer (Perkin Elmer Analyst $700)^{7}$. The stocks of primary nutrients were calculated as follows

Stock of nutrient $(\mathrm{kg})=$ Area of the lake $($ ha $) \times$ depth of lake sediment $(\mathrm{m}) \times$ bulk density $\left(\mathrm{Mg} \mathrm{m}^{-3}\right) \times$ nutrient concentration $\left(\mathrm{mg} \mathrm{kg}^{-1}\right) \times 10^{-3}$.

The equivalence of lake sediments (up to $15 \mathrm{~cm}$ depth) to bags of urea, SSP (single super phosphate) and MOP (muriate of potash) in terms of available plant nutrients was calculated using the following formulae:

Equivalent bags $(50 \mathrm{~kg}$ each $)$ of urea $=(100 \times$ stock of $\mathrm{N}$ in the lake sediment $) /(46 \times 50)$.

Equivalent bags $(50 \mathrm{~kg}$ each $)$ of SSP $=(100 \times$ stock of $\mathrm{P}_{2} \mathrm{O}_{5}$ in the lake sediment $) /(16 \times 50)$.

CURRENT SCIENCE, VOL. 120, NO. 7, 10 APRIL 2021 
RESEARCH COMMUNICATIONS

Table 1. Location of nine lakes in Bengaluru, Karnataka, India and their extent

\begin{tabular}{lccc}
\hline Lake & Location & Area (ha) & Catchment area (ha) \\
\hline Madiwala & $12^{\circ} 54^{\prime} \mathrm{N}, 77^{\circ} 37^{\prime} \mathrm{E}$ & 114.3 & - \\
Lalbagh & $12^{\circ} 56^{\prime} \mathrm{N}, 77^{\circ} 35^{\prime} \mathrm{E}$ & 13 & - \\
Bellandur & $12^{\circ} 93^{\prime} \mathrm{N}, 77^{\circ} 66^{\prime} \mathrm{E}$ & 360 & 14,800 \\
Sankey Tank & $13^{\circ} 01^{\prime} \mathrm{N}, 77^{\circ} 57^{\prime} \mathrm{E}$ & 15 & 125.4 \\
Ulsoor & $12^{\circ} 58^{\prime} \mathrm{N}, 77^{\circ} 37^{\prime} \mathrm{E}$ & 50 & 150 \\
Yelahanka & $13^{\circ} 06^{\prime} \mathrm{N}, 77^{\circ} 34^{\prime} \mathrm{E}$ & 10 & - \\
Yediyur & $12^{\circ} 56^{\prime} \mathrm{N}, 77^{\circ} 34^{\prime} \mathrm{E}$ & 6.45 & - \\
Nagavara & $13^{\circ} 02^{\prime} \mathrm{N}, 77^{\circ} 36^{\prime} \mathrm{E}$ & 44 & - \\
Hebbal & $13^{\circ} 02^{\prime} \mathrm{N}, 77^{\circ} 35^{\prime} \mathrm{E}$ & 75 & - \\
\hline
\end{tabular}

Data not available.

Table 2. Methods used for the analysis of lake sediments

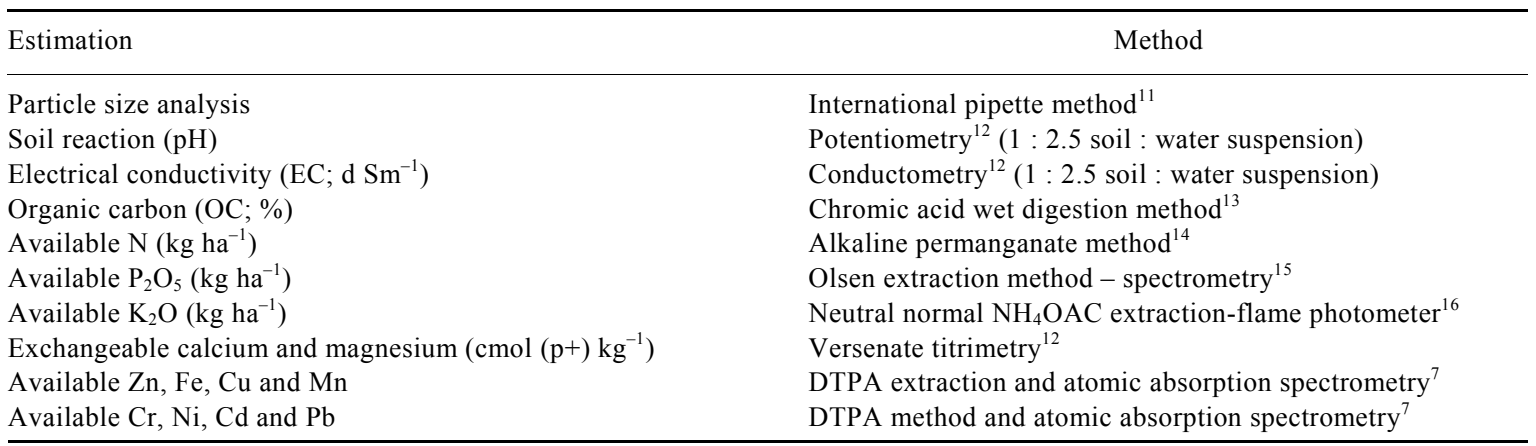

Table 3. Physico-chemical properties and primary nutrient concentration of tank sediments in Bengaluru

\begin{tabular}{lcccccc}
\hline Lake & $\mathrm{pH}$ & $\left.\mathrm{EC}(\mathrm{dS} \mathrm{m})^{-1}\right)$ & $\mathrm{OC}\left(\mathrm{g} \mathrm{kg}^{-1} \mathrm{sediment}^{-}\right.$ & $\mathrm{N}(\mathrm{ppm})$ & $\mathrm{P}(\mathrm{ppm})$ & $\mathrm{K}(\mathrm{ppm})$ \\
\hline Madiwala & 6.32 & 0.34 & 22.10 & 305.72 & 6.68 & 117.80 \\
Lalbagh & 8.15 & 0.53 & 19.30 & 293.08 & 6.65 & 117.68 \\
Bellandur & 6.15 & 0.34 & 25.60 & 253.18 & 6.84 & 123.47 \\
Sankey Tank & 7.50 & 0.76 & 22.10 & 284.61 & 7.20 & 122.76 \\
Ulsoor & 6.34 & 0.71 & 23.81 & 284.72 & 6.23 & 155.13 \\
Yelahanka & 7.15 & 0.65 & 18.50 & 238.54 & 8.60 & 154.82 \\
Yediur & 7.28 & 1.34 & 17.60 & 310.19 & 8.83 & 115.69 \\
Nagavara & 7.05 & 1.24 & 17.50 & 248.27 & 8.21 & 117.04 \\
Hebbal & 7.53 & 0.91 & 11.50 & 235.90 & 11.07 & 159.97 \\
Mean & 7.05 & 0.76 & 19.78 & 272.69 & 7.81 & 131.60 \\
\hline
\end{tabular}

Equivalent bags $(50 \mathrm{~kg}$ each $)$ of $\mathrm{MOP}=(100 \times$ stock of $\mathrm{K}_{2} \mathrm{O}$ in the lake sediment $) /(60 \times 50)$.

Urea, SSP and MOP contain $46 \%, 16 \%$ and $60 \%$ of N, $\mathrm{P}_{2} \mathrm{O}_{5}$ and $\mathrm{K}_{2} \mathrm{O}$ respectively.

Texture analysis provides an estimate of the relative distribution of sand, silt and clay in a given sample. The texture of tank sediments is a function of soil type, topography, rainfall intensity, crop cover and organic matter content of soils in the catchment area. The presence of finer fractions in tank sediments is indicative of the transportation of silt and clay particles with run-off water through erosion. In this study, fine sand in the samples ranged from $12 \%$ to $53 \%$, whereas silt and clay content ranged from $30 \%$ to $71 \%$. Texture analysis of lake sedi- ments revealed similarities in soil type of the lake sediments and surrounding areas, indicating erosion of the topsoil layers. The $\mathrm{pH}$ of nine lakes of Bengaluru ranged from 6.15 to 8.15 (Table 3). The $\mathrm{pH}$ of Bellandur and Madiwala lakes was acidic and Lalbagh lake was in the alkaline range, whereas the others were neutral. Since crops differ in their sensitivity towards soil $\mathrm{pH}$, use of sediments should be based on the type of crops to be grown. Sediments with high $\mathrm{pH}$ should preferably not be applied to high-pH soils and vice versa, as it may adversely affect soil health. Electrical conductivity (EC) is an indicator of the presence of dissolved salts in the sediments that might be added through surface run-off. $\mathrm{EC}$ in all the lake sediments under study was within safe limits $\left(<2 \mathrm{dS} \mathrm{m}^{-1}\right)$. The available nitrogen content varied 
Table 4. Secondary nutrient concentration of tank sediments in Bengaluru

\begin{tabular}{lccl}
\hline Lake & $\mathrm{Ca}\left(\mathrm{meq} \mathrm{l}^{-1}\right)$ & $\mathrm{Mg}\left(\mathrm{meq} \mathrm{l}^{-1}\right)$ & $\mathrm{S}(\mathrm{ppm})$ \\
\hline Madiwala & 7.13 & 3.76 & 26.65 \\
Lalbagh & 6.13 & 3.92 & 16.55 \\
Bellandur & 5.13 & 2.92 & 27.34 \\
Sankey Tank & 7.18 & 3.73 & 36.65 \\
Ulsoor & 6.29 & 2.92 & 31.65 \\
Yelahanka & 6.85 & 3.54 & 76.55 \\
Yediur & 6.69 & 2.74 & 41.98 \\
Nagavara & 6.51 & 2.80 & 33.59 \\
Hebbal & 7.30 & 3.73 & 45.65 \\
Mean & 6.58 & 3.34 & 37.40 \\
\hline
\end{tabular}

Table 5. Micronutrients concentration of tank sediments in Bengaluru

\begin{tabular}{lrrrc}
\hline Lake & $\mathrm{Cu}(\mathrm{ppm})$ & $\mathrm{Fe}(\mathrm{ppm})$ & $\mathrm{Zn}(\mathrm{ppm})$ & $\mathrm{Mn}(\mathrm{ppm})$ \\
\hline Madiwala & 8.79 & 8.14 & 0.05 & 5.05 \\
Lalbagh & 3.13 & 8.12 & 0.05 & 7.23 \\
Bellandur & 4.64 & 20.28 & 6.40 & 5.81 \\
Sankey Tank & 1.79 & 7.82 & 5.88 & 3.15 \\
Ulsoor & 1.78 & 19.79 & 0.07 & 5.96 \\
Yelahanka & 3.54 & 18.12 & 0.06 & 5.75 \\
Yediur & 8.33 & 9.09 & 0.06 & 9.36 \\
Nagavara & 8.53 & 8.77 & 0.05 & 11.1 \\
Hebbal & 11.81 & 12.65 & 0.06 & 4.23 \\
Mean & 5.81 & 12.53 & 2.52 & 5.51 \\
\hline
\end{tabular}

from $235.90 \mathrm{ppm}$ in Hebbal lake to $310.19 \mathrm{ppm}$ in Yediur lake (Table 3). The mean nitrogen concentration recorded in all the nine lakes was $272.69 \mathrm{ppm}$. The higher concentration of nitrogen in silt suggests significant run-off losses of applied nitrogen fertilizers from agricultural fields. Padmaja et al. ${ }^{5}$ also recorded high $\mathrm{N}$ concentration in tank silt in the Medak district of Andhra Pradesh. Regular addition of high amounts of nitrogen is responsible for eutrophication in the surface water bodies and may cause nitrate pollution in groundwater. Among the nine lakes studied, the organic carbon (OC) concentration was highest in Bellandur lake $\left(25.60 \mathrm{~g} \mathrm{~kg}^{-1}\right.$ sediment $)$ and least in Hebbal lake (11.50 $\mathrm{g} \mathrm{kg}^{-1}$ sediment). OC content was higher in lake sediments compared to the nearby agricultural fields due to erosion of the topsoil layer and subsequent deposition in the lakes. In waterlogged condition, oxidation of $\mathrm{OC}$ is not possible, due to which loss of $\mathrm{C}$ decreases and thus $\mathrm{C}$ stock may build up with time ${ }^{8}$. Application of OC-rich sediments may improve soil health and stimulate microbial proliferation, as it is an important indicator of soil quality. The maximum available $\mathrm{P}$ content was recorded in Hebbal lake (11.07 ppm) followed by Yediur lake (8.83 ppm) (Table 3). Available potassium content ranged from 115.69 to $159.97 \mathrm{ppm}$, with mean concentration of $131.60 \mathrm{ppm}$. The concentration of calcium varied from $5.13 \mathrm{meq}^{-1}$ in Bellandur lake to $7.30 \mathrm{meq}^{-1}$ in Hebbal lake sediments (Table 4).
Similarly, the magnesium content ranged from 2.74 to $3.92 \mathrm{meq}^{-1}$. Higher concentration of alkali earth metals signifies their probable use as soil amendment in acidic soils. Higher sulphur content was recorded in Yelahanka lake (76.55 ppm) followed by Hebbal lake (45.65 ppm). The concentration of cationic micronutrients, e.g. $\mathrm{Cu}$ $(1.78-11.81 \mathrm{ppm}), \quad \mathrm{Fe} \quad(7.82-20.28 \mathrm{ppm}), \quad \mathrm{Zn} \quad(0.05-$ $6.40 \mathrm{ppm})$ and $\mathrm{Mn}(3.15-11.1 \mathrm{ppm})$ was variable (Table $5)$. The concentration of micronutrients in lake sediments was a function of the degree of soil erosion, and the amount of micronutrients added in the nearby agricultural fields and other point sources (domestic and industrial outlets). Traces of heavy metals, viz. $\mathrm{Ni}, \mathrm{Cr}, \mathrm{Cd}$ and $\mathrm{Pb}$ were found in the sediment samples. The concentration of $\mathrm{Ni}$ was maximum in Bellandur lake sediments (3.02 ppm), which is the sink of many industrial waste outlets, and minimum in Lalbagh lake (0.026 ppm) (Table 6). Sankey Tank was found to be highly contaminated with $\mathrm{Cr}$ and $\mathrm{Cd}$. $\mathrm{Pb}$ content varied from 0.003 to $0.488 \mathrm{ppm}$ in the nine lakes. Heavy metals in soil sediments can be translocated to the plant system and may contaminate the food chain ${ }^{9}$. Thus, build-up of heavy metals in sediments should be prevented in order to use them as a nutrient source and soil amendment.

The nitrogen stock depends on the concentration of nitrogen, bulk density of the sediments and area of the lake. Maximum nitrogen stock in the upper $15 \mathrm{~cm}$ of lake 
RESEARCH COMMUNICATIONS

\begin{tabular}{lcccc}
\hline Lake & Ni (ppm) & Cr (ppm) & Cd (ppm) & Pb (ppm) \\
\hline Madiwala & 0.15 & 0.186 & 0.29 & 0.003 \\
Lalbagh & 0.026 & 0.025 & 0.001 & 0.035 \\
Bellandur & 3.02 & 6.55 & 0.002 & 0.009 \\
Sankey Tank & 0.218 & 8.92 & 5.83 & 0.431 \\
Ulsoor & 0.375 & 0.214 & 0.003 & 0.488 \\
Yelahanka & 0.027 & 0.025 & 0.262 & 0.041 \\
Yediur & 0.242 & 0.354 & 0.515 & 0.427 \\
Nagavara & 0.027 & 0.019 & 0.036 & 0.004 \\
Hebbal & 0.265 & 0.326 & 0.227 & 0.441 \\
Mean & 0.483 & 1.846 & 0.796 & 0.209 \\
\hline
\end{tabular}

Table 7. Available $\mathrm{N}$ concentration and stock in Bengaluru lakes

\begin{tabular}{|c|c|c|c|c|c|c|}
\hline Lake & $\begin{array}{c}\mathrm{N} \\
(\mathrm{ppm})\end{array}$ & $\begin{array}{l}\text { Bulk density } \\
(\mathrm{BD})\left(\mathrm{Mg} \mathrm{m}^{-3}\right)\end{array}$ & $\begin{array}{l}\text { N content } \\
(\mathrm{kg} / \mathrm{ha})\end{array}$ & $\begin{array}{l}\text { Area of the } \\
\text { lakes (ha) }\end{array}$ & $\begin{array}{l}\text { Total } \mathrm{N} \text { content in } \\
\text { the top } 15 \mathrm{~cm}(\mathrm{~kg})\end{array}$ & $\begin{array}{l}\text { No. of urea bags } \\
\qquad(50 \mathrm{~kg})\end{array}$ \\
\hline Madiwala & 305.72 & 1.02 & 467.7516 & 114.3 & $53,464.01$ & 2,325 \\
\hline Lalbagh & 293.08 & 1.01 & 444.0162 & 13 & $5,772.21$ & 251 \\
\hline Bellandur & 253.18 & 1.13 & 429.1401 & 360 & $154,490.40$ & 6,717 \\
\hline Sankey Tank & 284.61 & 1.08 & 461.0682 & 15 & $6,916.02$ & 301 \\
\hline Ulsoor & 284.72 & 1.16 & 495.4128 & 50 & $24,770.64$ & 1,077 \\
\hline Yelahanka & 238.54 & 1.1 & 393.591 & 10 & $3,935.91$ & 171 \\
\hline Yediur & 310.19 & 1.03 & 479.2436 & 6.45 & $3,091.12$ & 134 \\
\hline Nagavara & 248.27 & 1.05 & 391.0253 & 44 & $17,205.11$ & 748 \\
\hline Hebbal & 235.9 & 1.17 & 414.0045 & 75 & $31,050.34$ & 1,350 \\
\hline
\end{tabular}

Table 8. Available $\mathrm{P}_{2} \mathrm{O}_{5}$ concentrations and stocks in Bengaluru lakes

\begin{tabular}{lcccrr}
\hline Lake & $\begin{array}{c}\mathrm{P} \\
(\mathrm{ppm})\end{array}$ & $\begin{array}{c}\mathrm{BD} \\
\left(\mathrm{Mg} \mathrm{m}^{-3}\right)\end{array}$ & $\begin{array}{c}\mathrm{P}_{2} \mathrm{O}_{5} \text { content } \\
(\mathrm{kg} / \mathrm{ha})\end{array}$ & $\begin{array}{c}\text { Area of the } \\
\text { lakes (ha) })\end{array}$ & $\begin{array}{c}\text { Total } \mathrm{P}_{2} \mathrm{O}_{5} \text { stock in } \\
\text { the top } 15 \mathrm{~cm}(\mathrm{~kg})\end{array}$ \\
\hline Madiwala & 6.68 & 1.02 & 23.40 & 114.3 & $\begin{array}{c}\text { No. of single super } \\
\text { phosphate bags }(50 \mathrm{~kg})\end{array}$ \\
Lalbagh & 6.65 & 1.01 & 23.07 & 13 & 334 \\
Bellandur & 6.84 & 1.13 & 26.54 & 360 & 299.92 \\
Sankey Tank & 7.2 & 1.08 & 26.71 & 15 & 9557.92 \\
Ulsoor & 6.23 & 1.16 & 24.82 & 50 & 400.65 \\
Yelahanka & 8.6 & 1.1 & 32.49 & 10 & 1241.20 \\
Yediur & 8.83 & 1.03 & 31.24 & 6.45 & 324.95 \\
Nagavara & 8.21 & 1.05 & 29.61 & 44 & 201.50 \\
Hebbal & 11.07 & 1.17 & 44.48 & 75 & 1302.90 \\
\hline
\end{tabular}

sediments was observed in Bellandur lake, which is equivalent to 6717 bags of urea (Table 7). The $\mathrm{P}_{2} \mathrm{O}_{5}$ stock was also maximum in Bellandur lake due to its larger area. The available phosphorus stock in Bellandur lake was $9557.92 \mathrm{~kg}$, which is equivalent to $1195 \mathrm{bags}$ of SSP (Table 8). Available phosphorus stock in Hebbal, Ulsoor and Madiwala lakes was equivalent to 417,155 and 334 bags of SSP respectively. $\mathrm{K}_{2} \mathrm{O}$ concentration was maximum in Hebbal lake sediments $(336.89 \mathrm{~kg} / \mathrm{ha})$, but total potassium stock in the upper $15 \mathrm{~cm}$ layer was maximum in Bellandur lake $(90,409.67 \mathrm{~kg})$, which is equivalent to 3014 bags of MOP (Table 9). This is similar to the results of a study by Padmaja et $a .^{10}$ in the lake sediments of Medak district, Andhra Pradesh. In the present study, all the nine lakes showed noticeable stocks of primary plant nutrients. The application of these sediments as nutrient substitute for crop production will not only reduce the cost of production, but also increase the water storage capacity of these lakes.

In this study, sediments collected from all the nine lakes were found to be rich in available $\mathrm{N}, \mathrm{P}$ and $\mathrm{K}$. The cationic micronutrients were found to be higher than the average soil concentration. The physico-chemical properties like $\mathrm{pH}$ and $\mathrm{EC}$ were recorded within the critical 
RESEARCH COMMUNICATIONS

Table 9. Available $\mathrm{K}_{2} \mathrm{O}$ concentration and stocks in Bengaluru lakes

\begin{tabular}{|c|c|c|c|c|c|c|}
\hline Lake & $\begin{array}{c}\mathrm{K} \\
(\mathrm{ppm})\end{array}$ & $\begin{array}{c}\mathrm{BD} \\
\left(\mathrm{Mg} \mathrm{m}^{-3}\right)\end{array}$ & $\begin{array}{l}\mathrm{K}_{2} \mathrm{O} \text { content } \\
(\mathrm{kg} / \mathrm{ha})\end{array}$ & $\begin{array}{l}\text { Area of the } \\
\text { lakes (ha) }\end{array}$ & $\begin{array}{l}\text { Total } \mathrm{K}_{2} \mathrm{O} \text { stock } \\
\text { in the top } 15 \mathrm{~cm}\end{array}$ & $\begin{array}{c}\text { No. of muriate of } \\
\text { potash bags }(50 \mathrm{~kg})\end{array}$ \\
\hline Madiwala & 117.8 & 1.02 & 216.28 & 114.3 & 24720.90 & 824 \\
\hline Lalbagh & 117.68 & 1.01 & 213.94 & 13 & 2781.24 & 93 \\
\hline Bellandur & 123.47 & 1.13 & 251.13 & 360 & 90409.67 & 3014 \\
\hline Sankey Tank & 122.76 & 1.08 & 238.64 & 15 & 3579.68 & 119 \\
\hline Ulsoor & 155.13 & 1.16 & 323.91 & 50 & 16195.57 & 540 \\
\hline Yelahanka & 154.82 & 1.1 & 306.54 & 10 & 3065.43 & 102 \\
\hline Yediur & 115.69 & 1.03 & 214.48 & 6.45 & 1383.45 & 46 \\
\hline Nagavara & 117.04 & 1.05 & 221.20 & 44 & 9733.04 & 324 \\
\hline Hebbal & 159.97 & 1.17 & 336.89 & 75 & 25267.26 & 842 \\
\hline
\end{tabular}

limits. Higher concentration of OC was recorded in all the sediment samples. The tank silt obtainable from Bellandur lake up to a depth of $15 \mathrm{~cm}$ was equivalent to 6717 bags of urea, 1195 bags of SSP and 3014 bags of MOP. Since heavy metals concentration was found to be within safe limits, there is hardly any chance of heavy metals pollution in agricultural fields. Thus, sediments from all these lakes can be used as a nutrient substitute for crop production. This will increase water storage of the lakes, reduce the cost of cultivation and will increase farmers' income.

1. Jumbe, A. S., Nandini, N. and Tandon, S., Bangalore lakes issues and perspectives on pollution, restoration and management. In Proceedings of the 12th World Lake Conference, Jaipur, 2007.

2. Lokeshwari, H. and Chandrappa, G. T., Impact of heavy metal contamination of Bellandur lake on soil and cultivated vegetation. Curr. Sci., 2006, 91(5), 622-627.

3. Anon., Monitoring and analysis of tanks and lakes of Bangalore. In Annual Report of Karnataka State Pollution Control Board Research and Development Wing Publication, 2001.

4. Anon., Vision for village tanks of Tamil Nadu. In Proceedings of the Development of Humane Action (DHAN Foundation), Madurai, 2004, pp. 1-34.

5. Padmaja, K. V., Wani, S. P., Agarwal, L. and Sahrawat, K. L., Economic assessment of desilted silt in terms of plant nutrients equivalent: a case study in the Medak district of Andhra Pradesh. In Global Theme 3: Water, Soil and Agrodiversity Management for Ecosystem Resilience, Report No. 4, International Crops Research Institute for the Semi-Arid Tropics, Patancheru, India, 2003, p. 24.

6. Sudhira, H. S., Ramachandra, T. V. and Bala Subrahmanya, M. H., City profile Bangalore. Cities, 2007, 24(5), 379-390.

7. Lindsay, W. L. and Norvell, W. A., Development of DTPA soil test Zn, Fe, Mn and Cu. J. Am. Soil Sci. Soc., 1978, 42, 421-428.
8. Saharwat, K. L., Organic matter accumulation in submerged rice soils. Adv. Agron., 2004, 81, 169-201.

9. Varalakshmi, L. R. and Ganeshamurthy, A. N., Heavy metal contamination of water bodies, soils and vegetables in peri urban areas of Bangalore city of India. In Proceedings of the 19th World Congress of Soil Science, Brisbane, Australia, 2010, p. 37.

10. Padmaja, K. V., Wani, S. P., Sahrawat, K. L. and Jangawad, L. S., Economic evaluation of sediments as a source of plant nutrients. Curr. Sci., 2008, 95(8), 1042-1050.

11. Piper, C. S., Soil and Plant Analysis, Hans Publishers, Bombay, 1966.

12. Jackson, M. L., Soil Chemical Analysis, Prentice Hall of India Pvt Ltd, New Delhi, 1973, p. 498.

13. Walkely, A. and Black, C. A., An examination of the method determining soil organic matter and proposed modification of the chromic acid filtration method. Soil Sci., 1934, 37, 29-38.

14. Subbiah, B. V. and Asija, G. L., A rapid procedure for the estimation of available nitrogen in soils. Curr. Sci., 1956, 25, 259-260.

15. Olsen, S. R., Col, C. L., Wattanabe, F. S. and Dean, D. A., Estimation of available phosphorus in soils by extraction with sodium bicarbonate. Licenciate thesis, Swedish Institute for Infectious Disease Control, Royal Institute of Technology, Stockholm, Sweden, 1954.

16. Stanford, S. L. and English, L., Use of flame photometer in rapid soil tests of K and Ca. Agron. J., 1949, 55, 446-497.

ACKNOWLEDGEMENTS. We thank the University of Agricultural Sciences, Bengaluru for providing the necessary facilities to carry out this study. The first author thanks the Indian Council of Agricultural Research, New Delhi for extending financial support under Junior Research Fellowship during the course of this study.

Received 28 May 2018; accepted 10 November 2020

doi: $10.18520 / \mathrm{cs} / \mathrm{v} 120 / \mathrm{i} 7 / 1250-1254$ 